\title{
Research Article \\ Biochemical changes in Conocarpus species under saline soils of Lal Suhanra National Park, Bahawalpur
}

\author{
Amjad Saeed ${ }^{1}$, Tanveer Hussain ${ }^{1}$, Anum choudry', Muhammad Umair ${ }^{2}$, Muhammad Altaf ${ }^{1}$, Umair Riaz', Ahtesham \\ ul Hassan', Muhammad Asif Khan ${ }^{3}$, Zafar Iqbal ${ }^{4}$, Mansoor Ali', Rana Haroon Maqsood, Muhammad Furqan \\ Shaheen ${ }^{5}$
}

Citation: Saeed A.; Hussain T.; Choudry A.; Umair M.; Altaf M.; Riaz U.; Hassan A.; Khan MA.; Iqbal Z.; Ali M.; Maqsood RH.; Shaheen MF. Biochemical changes in Conocarpus species under saline soils of Lal Suhanra National Park, Bahawalpur. Pakistan Journal of Biochemistry and Biotechnology,2021, 2 (2), 207-218.

https://doi.org/10.52700/pjbb.v2i2.85

Received: 06-11-2021

Accepted: 26-12-2021

Published: 31-12-2021
1 Department of Forestry, Range and Wildlife Management, The Islamia University of Bahawalpur, Punjab Pakistan

2 Department of Chemistry and Life Science, Zhejiang Normal University, Jinhua 321004, China

3 Key laboratory of Silviculture and Conservation, Beijing Forestry University, Beijing 10083, China

4 Federal Seed Certification \& Registration Department Bahawalpur

5 University of Agriculture Faisalabad

"Corresponding author: amjadsaeed101@gmail.com

Abstract: In Pakistan, arid and semi-arid areas are more prone to limited rainfall, extensive evapo-transpiration and higher temperatures. For better understandings of current situation, a field experiment was carried out to study the morphological characteristics, biochemical responses and ionic composition of Conocarpus species (Conocarpus erectus and Conocarpus lancifolius) under saline soil conditions in Lal Suhanra National Park, Bahawalpur during 2019-21. Three sites one at normal soil and two at different salinity levels (Medium and High Salinity) were observed in order to assess their effect on plant growth and other parameters. The data regarding physiological and biochemical parameters were recorded. Conocarpus lancifolius and Conocarpus erectus has maximum (233) $\mathrm{mmol} \mathrm{m}^{-2} \mathrm{sec}^{-1}$ and (162) $\mathrm{mmol} \mathrm{m}^{-2} \mathrm{sec}^{-1}$ stomatal conductance respectively. Maximum transpiration rate (4.57 $\left.\mathrm{MMOL} \mathrm{M}^{-2} \mathrm{~S}^{-1}\right)$ was observed at site-I in case of C. lancifolius, while maximum transpiration rate in case of $C$. erectus was $\left(2.94 \mathrm{MMOL} \mathrm{M}^{-2} \mathrm{~S}^{-1}\right)$ at site-I. At control level, maximum photosynthetic rate was measured as $\left(8.76 \mu \mathrm{mol} \mathrm{m}-2 \mathrm{sec}^{-1}\right)$ in $C$. lancifolius and $\left(5.59 \mu \mathrm{mol} \mathrm{m}^{-2} \mathrm{sec}^{-1}\right)$ in case of $\mathrm{C}$. erectus. Conocarpus lancifolius and Conocarpus erectus has maximum SOD (13.29 and 19.62) and CAT (16.48 and 42.05), and POD (14.81 and $8.81 \mathrm{U} / \mathrm{mg}$ protein) respectively. Maximum values of $\mathrm{Na}^{+} \mathrm{K}^{+}$ratio in leaves (3.08), shoots (5.98) and roots (9.84) were detected at site-I in C. lancifolius. Based on statistically analyzed data, it is revealed that Conocarpus lancifolius can tolerate better salt stress as compared to Conocarpus erectus. Both species of Conocarpus can tolerate salinity up to $25 \mathrm{dSm}^{-1}$ but growth of Conocarpus erectus is affected more as compared to Conocarpus lancifolius.

Keywords: Arid, evapo-transpiration, morphological, ionic, physiological, transpiration.

\section{Introduction}

Crop production and forest yield have been reduced due to climatic variation in term of flooding, insufficient irrigation management, inadequate ions leaching and saline water usage [1,2]. Poor soil management practices, high evapo-transpiration, poor water conditions [3] and low rainfall are some prominent factors of salinity in arid and semi-arid regions of the world [4]. Crop yields are constantly being reduced due to salinity [5]. The major province (Punjab) of Pakistan in term of agricultural production is also a victim of salinity and it was found that the most of the pumped ground water $(75-80 \%)$ is not suitable for the irrigation, which can be harmful for the production of various crops. It was observed that, about $14 \%$ of the whole irrigated lands are salt affected. Similarly, it is increasing at 40,000 hectares on annual basis [6].

Level of salinity highly matters for slow growth and death of different plant species. Soil and water with excess amount of soluble salt can reduced plant's growth and development. Nature has blessed plants with different abilities to cope with salt and water 
stress[Turner, 1986]. Due to strong salt tolerance genetic base, halophytes are considered the most salt-resistant/tolerant plants and can grow well in the presence of high soluble salts ranged from 125 to 5,000 parts per million. Excess of everything is bad, similarly, excessive water also damages root through reduced root respiration, depletion of oxygen, production of phototoxic compounds. These factors contribute to significant yield losses $[6,7]$.

It was observed that engineering and chemical approaches were more expensive as compare to others. This approach seemed to be not useful and unsustainable in case of salt affected soils. Family Combretaceae has two species of Conocarpus named as Conocarpus lancifolius and Conocarpus erectus, which are tree and shrub, respectively. Growing in low fertility soils and tolerating high temperatures (upto $47^{\circ} \mathrm{C}$ ) are some unique characteristics of Conocarpus species. Moreover, Conocarpus species are good source of food, which is very delicious for the wildlife and it can also protect the soil during the storm. Horticulture and Forestry department also receives services of Conocarpus erectus as an ornamental plant in parks, streets and parking $[8,9]$. Conocarpus erectus can serve as a medicinal plant, which is used for the treatment of many ailments i.e., anemia, fever, orchids, syphilis, diabetes, conjunctivitis, swellings and gonorrhea. Coastal and riverine areas of Yemen and Somalia are considered the native hubs of Conocarpus lancifolius. This specie is used in fuel, wood for buildings, boats and turnery and charcoal as it is the most durable one.Leaves and bark can also be used in tannery. Besides this, its shoots, roots and branches are also used for fodder purpose because it is soft, non-toxic and attractive plant [10]. Therefore, the current study was conducted to check the harmful effects of water and salt stress on two species of Conocarpus. In Pakistan, the researchers have not given due importance to the growth responses of these species against water and salinity stress. The results of the present study will be helpful for developing concrete strategy for the betterment of salt affected lands, which can be responsible for the extension of tree cover in Pakistan. Therefore, the aim of current study was planned i) to check the potential .;ps ii) for the evaluation of biochemical, morpho-physiological and ionic attributes for salt stress in Conocarpus, and iii) To investigate the comparative as well as ameliorative effects of two species of Conocarpus on the physicochemical properties of salt excessive soils.

\section{Materials and Methods}

A field experiment was planned to evaluate the part of Conocarpus lancifloius and Concarpus erectus in the reclamation of salt affected soils at Irrigated Plantation of Lal Suhanra National Park, Bahawalpur, district of Punjab, Pakistan. Half year-old sound plants were taken from the nursery of Punjab Forest Department, Bahawalpur. Then pits were established for the transplantation of these species effectively made in the study site for above mentioned reason at spacing of $6 \times 10$ on three unique locales of normal (site-I),medium (site-II) and high (Site-III) salinity levels.

\subsection{Measurements}

Plant growth parameters like stem diameter, plant height and number of branches were recorded after two years. Leaves were taken for ionic composition and biochemical analysis. Soil samples were collected from various depths for the study of several properties such as pH, SAR and EC. Organic matter, bulk density and infiltration rate of soil were also determined before planting and after the harvesting tree crop. The data analyzed and interpreted by using standard statistical design[Steel et al. 1997].

For the analysis of particle size, Hydrometer method was used. For the measurement of Bulk density, double ring core method was used. For the calculation of water infiltration rate, double-ring infiltrometer method was applied [11 Soil natural issue (OM) decided after the strategy Walkley-Black. $\mathrm{pH}$ of soil was noted by saturating $300 \mathrm{~g}$ soil with distilled water, while soil mass was allowed to stand overnight. Finally, $\mathrm{pH}$ of soil was note down with a $\mathrm{pH}$ meter. Electrical conductivity of the immersed remove was noted with the assistance of $\mathrm{EC}$ meter. The buffer solution of $\mathrm{NH}_{4} \mathrm{OH}$ and $\mathrm{NH}_{4} \mathrm{Cl}$ in the 
presence of saturated extract, while eriochrome black T-indicator was used to titrated against $0.01 \mathrm{~N}$ EDTA (Versinate solution) till bluish green point was gained at the end. A progression of $\mathrm{NaCl}(2,4,6,8,10,12,14$ and $16 \mathrm{ppm} \mathrm{Na}$ ) standard arrangements was utilized to institutionalize the Flame Photometer (Sherwood-410). Sodium adsorption ratio (SAR) was calculated in mmolc $\mathrm{L}^{-1}$.

For the measurements of sodium and potassium, Sherwood-410 Flame Photometer with the assistance of self-arranged standard arrangements utilizing reagent review salt of $\mathrm{NaCl}$ and $\mathrm{KCl}$, individually by Wolf [1982].For the extraction of antioxidant (enzymes), firstly we take fresh samples of leaf $(0.5 \mathrm{~g})$, then the sample was grounded with the help of a tissue grinder, which is treated with cold phosphate buffer ( $\mathrm{pH} 7.8$ ) solution of about $5 \mathrm{~mL}$ of $50 \mathrm{mM}$, while placed in an ice bath. For the homogenization, it was centrifuged at a rate of about $15000 \times \mathrm{g}$ per $20 \mathrm{~min}$ at a temperature of $4{ }^{\circ} \mathrm{C}$. The supernatant was used for the fortitude of antioxidant (enzymes), supernatant was used. Turf action was noted by estimating its capacity to control the photoreduction of nitrobluetetrazolium (NBT) utilizing the strategy as depicted. With the end goal of exercises of catalase (CAT) and peroxidase (POD), strategy for Chance and Maehly [12] was utilized with a few alterations.

For the calculation of water potential $(\psi w)$ of leaves, Schlender type pressure chamber was taken. Calculation was done before the harvesting of plants. The leaf was firstly frozen at $-20^{\circ} \mathrm{C}$ in a deep freezer for one week. After that, the frozen material was melted and sap with the help a glass rod. For measuring the osmotic potential of sap, vapor pressure Osmometer was applied. Difference among the osmotic potential ( $\psi \mathrm{s}$ ) and water potential $(\psi w)$ detected the turgor potential values $\Psi \mathrm{p}=\psi \mathrm{w}-\psi \mathrm{s}$

\section{Results}

\section{Morphlogiacal Attributes}

Plant growth and stem diameter was maximum at site-I which have low salinity after 2 years transplantation. Two-year data regarding of plant growth showed that C. lancifolius species perform better than C. erectus in saline conditions (Fig. 1). Plant height, biomass and diameter decreased under salt stress. Interaction among the species and salinity was observed as significant $(\mathrm{p} \leq 0.05)$. Maximum plant height was measured in site-I for both species. Different sites have different diameter of plants, as $(5.45) \mathrm{cm}$ on site-I, $(4.45) \mathrm{cm}$ on site-II and (3.59) on site-III for C. lancifolius were noted. Maximum reduction was noted in C. erectus was $(0.59) \mathrm{cm}$ at site-III, while minimum reduction was noted $(0.92$ $\mathrm{cm}$ ) at site-I. While regarding plant biomass, maximum plant biomass was showed by $C$. lancifolius as compared to C. erectus. In C. lancifolius, maximum plant biomass was noted at site-I (6522 g) under low salinity level as compare to site-III (3972 g). While in C. erectus, maximum reading in above ground biomass was (1717 g) at site-III.
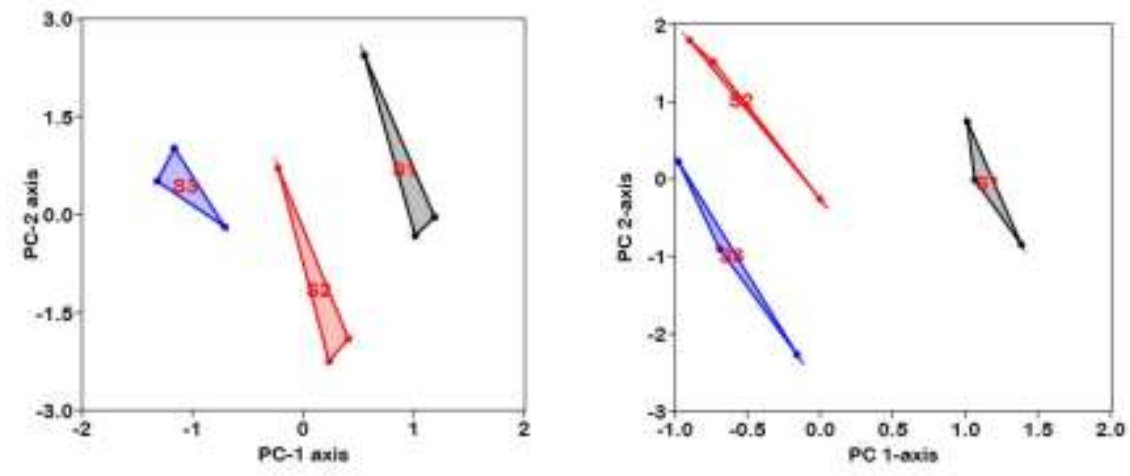
(b)

(a)

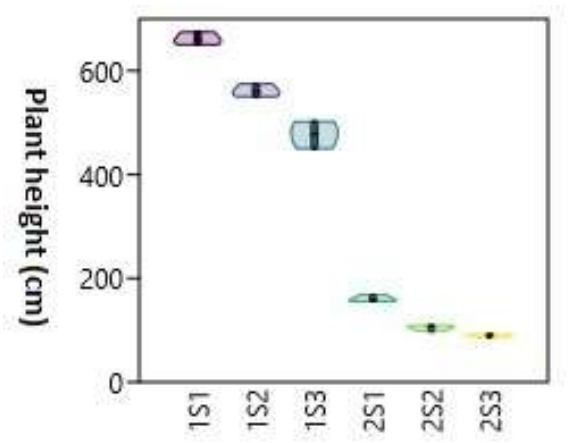

Salinity levels

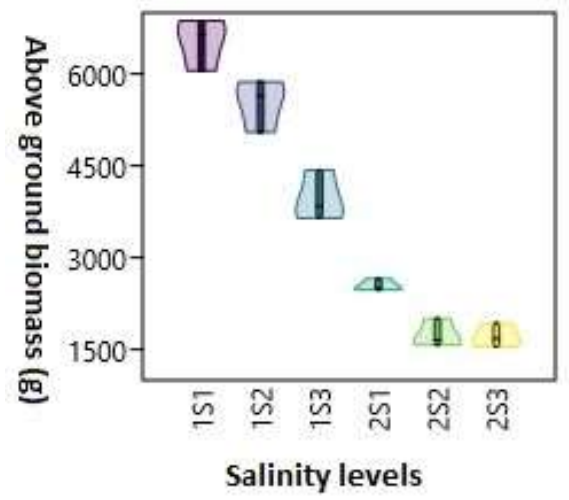

(c)

(d)

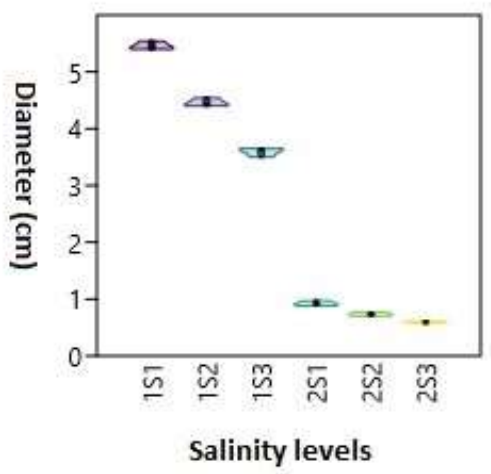

(e)

Fig 1: Morphological adaptations of Conocarpus under different salinity levels

\section{Physiological attributes}

The maximum chlorophyll content was noted at site-I (59.43) in C. lancifolius whereas the minimum chlorophyll content was observed at site-III (38.9) in C. erectus (Fig..2 a). Salinity significantly reduced the photosynthetic rate in both species (Fig. 3.2 b). C. lancifolius showed better photosynthetic rate as compared to C. erectus in all salinity levels. At control level, maximum photosynthetic rate was $8.76 \mu \mathrm{mol} \mathrm{m}^{-2} \mathrm{sec}^{-1}$ in C. lancofolius and $5.59 \mu \mathrm{mol} \mathrm{m} \mathrm{mec}^{-1}$ in case of C. erectus. In case of water use efficiency, both species showed less water use efficiency as salinity level increased (Fig. 3.2 c). Maximum reduction in water use efficiency was 0.89 in C. erectus at site-III.

Transpiration rate of both species decreased as compare to control under salt stress (Fig. 3.2.d). Regarding species, C. lancifolius show better transpiration rate as compare to $C$. 
erectus. Maximum reduction in transpiration rate was 4.57 (MMOL $\left.\mathrm{M}^{-2} \mathrm{~S}^{-1}\right)$ at site-I observed in case of $C$. lancifolius under high salinity on the other hand maximum reduction in case of C. erectus was 2.94 (MMOL M-2 $^{-2} \mathrm{~S}^{-1}$ ) at site-I when salt stress was normal. Stomatal conductance has similar effect to transpiration rate and photosynthetic rate. Reduction in stomatal conductance was decreased with increase in salinity level and drought level. At control condition, stomatal conductance was maximum with mean value $233 \mathrm{mmol} \mathrm{m}^{-2} \mathrm{sec}^{-1}$ in C. lancifolius and $162 \mathrm{mmol} \mathrm{m}^{-2} \mathrm{sec}^{-1}$ in case of C. erectus. These results indicated that $C$. lancfolius perform better than $C$. erectus regarding stomatal conductance (Fig. 3.2 e). Maximum water potential was noted as 3.67 at site-III in C. erectus, whereas minimum was observed at site-I in C. lancifolius. (1.67). Maximum turgor potential was (0.87) at site-I in C. lancifolius and minimum was 0.43 in C. erectus at site-III. Maximum osmotic potential was recorded in C. erectus at site-III and minimum was (2.6) at site-I for C. lancifolius (Fig.2).

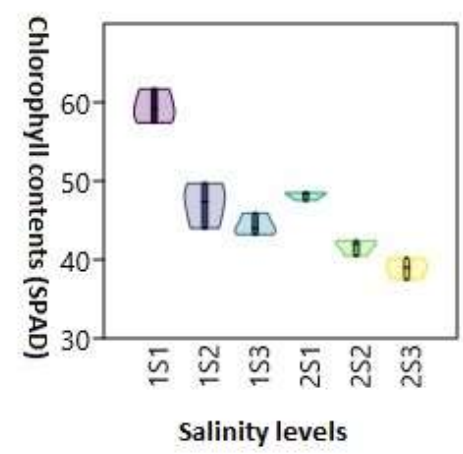

(a)

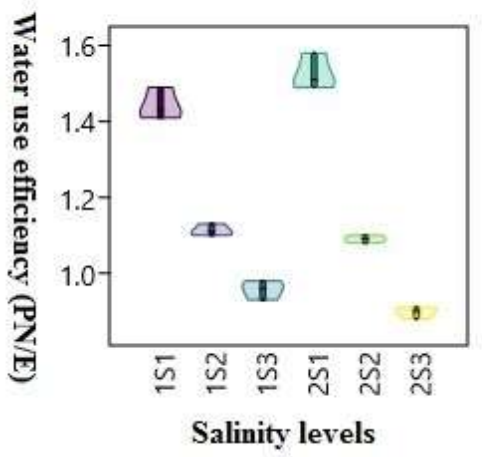

(c)

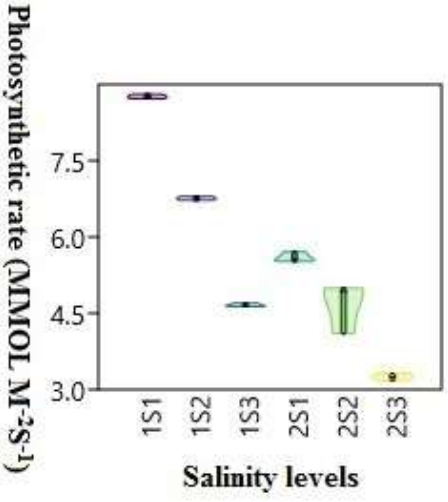

(b)

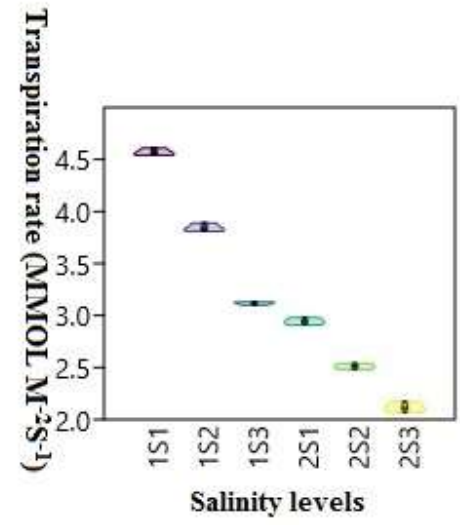

(d) 


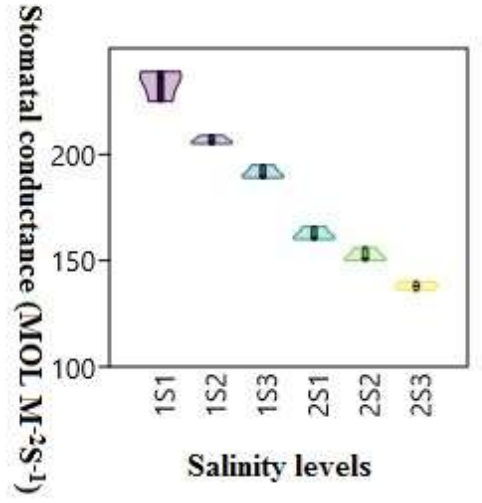

(e)

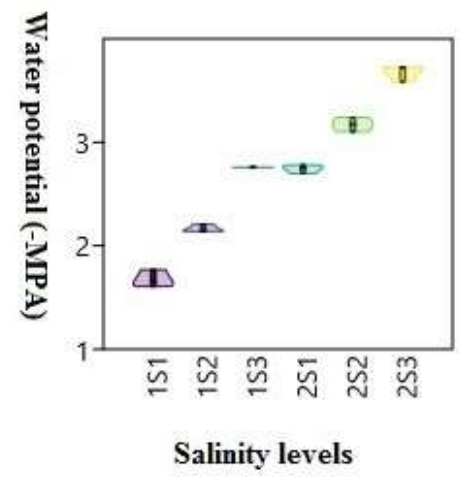

(f)

Fig. 2: Physiological adaptations of Conocarpus under different salinity levels

\section{Ionic composition}

Conocarpus species under salt stress perform differently. Their ionic composition was changed when submitted to salinity. Salinity significantly enhanced leaf sodium $\left(\mathrm{Na}^{+}\right)$, shoot sodium $\left(\mathrm{Na}^{+}\right)$content (Fig..). After determination of $\mathrm{Na}^{+}$and Potassium in leaves, shoot and roots, we also calculated the $\mathrm{K}^{+} \mathrm{N}^{+}$ratio. In case of $\mathrm{K}^{+} \mathrm{N}^{+}$ratio in shoot, maximum ratio was observed at site-I (5.98)while minimum was found at site-III (1.25) for C. lancifolius. C. lancifolius showed better $\mathrm{K}^{+} \mathrm{N}^{+}$ratio than that of C. erectus . Maximum $\mathrm{K}^{+}: \mathrm{Na}^{+}$ratio in leaves was observed at site-I in C. lancifolius followed by at site-II and site-III. Whereas the minimum $\mathrm{K}^{+} \mathrm{Na}^{+}$ratio was observed at site-III (0.94) in the shoot, (1.13) in roots and (0.61) in leaves for C. erectus (Fig. 3).

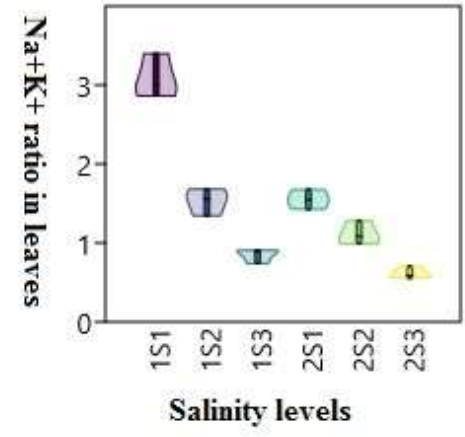

(a)

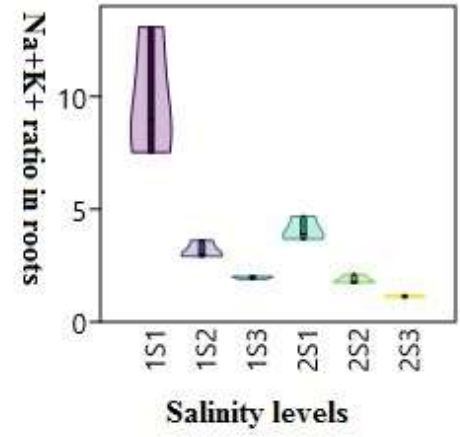

(b) 


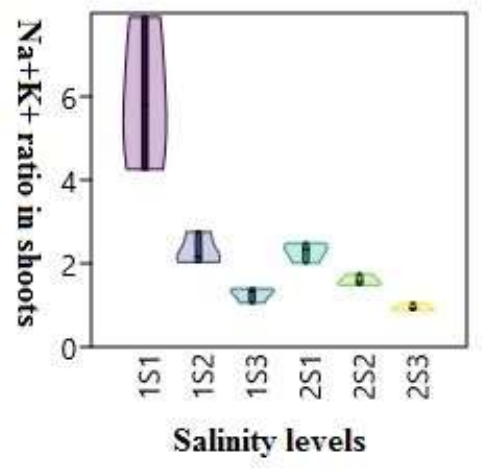

(c)

Fig. 3: Ionic composition of Conocarpus under different salinity levels

\subsection{Soil properties}

Soil examination of experimental site indicated the saline sodic soil on the basis of value of $\mathrm{pHs}$, ECe and SAR. In each plot the value of $\mathrm{pHs}$, ECe and SAR was different, which indicated the differences in growth. At transplanting of plants, the size of seedling was same but increase in plant after transplantation indicated experimental effects. With the time, value of soil parameter ( $\mathrm{pHs}$, ECe and SAR) decreased, this reduction is more in C. lancifolius than $C$. erectus. Comparison of species indicated that $\mathrm{pH}$ value decreased with time due to plant growth (Table-1) This reduction in $\mathrm{pH}$ was more in case of $C$. lancifolius. In case of soil ECe, both species showed reduction in ECe value due to uptake of salts in plant body. Highest reduction in ECe was observed in C. lancifolius after two years of transplanting of tress. The value of ECe was (3.37)at site- I,(12.49) at site-II and(16.07) at site-III in case of $C$. lancifolius. While in case of $C$. erectus, the value ECe was (4.34) at site- I, (14.06) at site- II, (18.79) at site- III and. The reduction in ECe was due to planting of salt tolerant plant which uptake the salts in their body. Further, their interaction was also significant $(\mathrm{p} \leq 0.05)$ (Table-2).

After transplanting of seedling, the addition of leaf litter increased the soil organic content due to decomposition of leaf litter after time. After two year of plants maximum organic content was measures at site- I which was less in C. erectus, while more in case of C. lancifolius. Maximum increase in OM was (2.15)\% in C. lancifolius at site- I, while minimum was (1.59)\% at site-III in C. erectus (Table-4).

Regarding bulk density, maximum bulk density was (1.23)\% in C. erectus after 2 years of tree transplanting at site- III, while minimum was (1.13)\% at site- Iin C. lancifolius(Table-5). Results also indicated that increase in salinity decreased the bulk density in both species. Regarding infiltration rate, both species increased infiltration rate after two years due to increase in root biomass. Moreover, the interaction between species and salinity was measured as significant $(\mathrm{p} \leq 0.05)$. For all the sites, infiltration rate was increased due to plantation. Maximum increase in infiltration rate was at site- I cmh-1 which was $(0.63) \%$ more at the time of transplanting for C. lancifolius. Minimum increase was at siteIII which was $(0.44) \%$ in C. erectus. Regarding the species, increase in infiltration speed was recorded highest in C. lancifolius as compared to C. erectus (Table-6). 
Table-1: Effect of Conocarpus species on soil $\mathrm{pH}$

\begin{tabular}{llll}
\hline Treatments & Initial values & $\begin{array}{l}\text { C. lancifolius } \\
\text { (After 2yrs) }\end{array}$ & $\begin{array}{l}\text { C. erectus } \\
\text { (After 2yrs) }\end{array}$ \\
\hline Site - I & 7.80 & 7.64 & 7.75 \\
Site - II & 7.86 & 7.64 & 7.75 \\
Site - III & 8.45 & 7.73 & 7.95 \\
\hline
\end{tabular}

Table-2: Effect of Conocarpus species on soil ECe $\left(\mathrm{dS} \mathrm{m}^{-1}\right)$

\begin{tabular}{llll}
\hline Treatments & Initial values & $\begin{array}{l}\text { C. lancifolius } \\
\text { (After 2yrs) }\end{array}$ & $\begin{array}{l}\text { C. erectus } \\
\text { (After 2yrs) }\end{array}$ \\
\hline Site - I & 4.37 & 3.37 & 4.34 \\
Site - II & 17.67 & 12.49 & 14.06 \\
Site - III & 23.65 & 16.07 & 18.79 \\
\hline
\end{tabular}

Table-3: Effect of Conocarpus species on soil SAR $\left(\left(\mathrm{mmol} \mathrm{L}^{-1}\right)^{1 / 2}\right)$

\begin{tabular}{llll}
\hline Treatments & Initial values & $\begin{array}{l}\text { C. lancifolius } \\
\text { (After 2yrs) }\end{array}$ & $\begin{array}{l}\text { C. erectus } \\
\text { (After 2yrs) }\end{array}$ \\
\hline Site - I & 31.84 & 14.09 & 19.6 \\
Site - II & 41.87 & 22.43 & 27.93 \\
Site - III & 50.69 & 41.34 & 44.42 \\
\hline
\end{tabular}

Table-4:Effect of Conocarpus species on soil organic matter percentage (\% age)

\begin{tabular}{llll}
\hline Treatments & Initial values & $\begin{array}{l}\text { C. lancifolius } \\
\text { (After 2yrs) }\end{array}$ & $\begin{array}{l}\text { C. erectus } \\
\text { (After 2yrs) }\end{array}$ \\
\hline Site - I & 1.89 & 2.15 & 1.9 \\
Site - II & 1.88 & 2.05 & 2.17 \\
Site - III & 1.31 & 1.75 & 1.59 \\
\hline
\end{tabular}

Table-5: Effect of Conocarpus species on soil bulk density $\left(\mathrm{g} \mathrm{cm}^{-3}\right)$

\begin{tabular}{llll}
\hline Treatments & Initial values & C. lancifolius & C. erectus \\
\hline
\end{tabular}




\begin{tabular}{llll}
\hline & & (After 2yrs) & (After 2yrs) \\
\hline Site - I & 1.19 & 1.13 & 1.16 \\
Site - II & 1.24 & 1.19 & 1.22 \\
Site - III & 1.32 & 1.26 & 1.23 \\
\hline
\end{tabular}

Table-6: Effect of Conocarpus species on soil infiltration rate $\left(\mathrm{cm} \mathrm{hr}^{-1}\right)$

\begin{tabular}{llll}
\hline Treatments & Initial values & $\begin{array}{l}\text { C. lancifolius } \\
\text { (After 2yrs) }\end{array}$ & $\begin{array}{l}\text { C. erectus } \\
\text { (After 2yrs) }\end{array}$ \\
\hline Site - I & 0.54 & 0.63 & 1.16 \\
Site - II & 0.44 & 0.58 & 1.22 \\
Site - III & 0.39 & 0.47 & 1.23 \\
\hline
\end{tabular}

\section{Biochemical attributes}

The value of SOD increased in both species with increase in salinity level. Production of SOD at site-I was 13.29 and site-III (19.62) for C. lancifolius, while for C. erectus, it was noted as (10.68) at site-I and (16.52) at site-III. Maximum CAT was noted as (16.48) at site-III in C. lancifolius, while minimum was (42.05) at site-I in C. erectus. Activity of POD also improved under salt stress conditions in both species. So, production of these antioxidant in plant reduced the oxidative damage caused by the salinity and improve plant performance. Maximum protein (5.22) was noted in site-I for C. lancifolius whereas minimum was observed at site-III amounted (1.89) in C. erectus. At high salinity level C. lancifolius perform better than C. erectus (Fig.4).

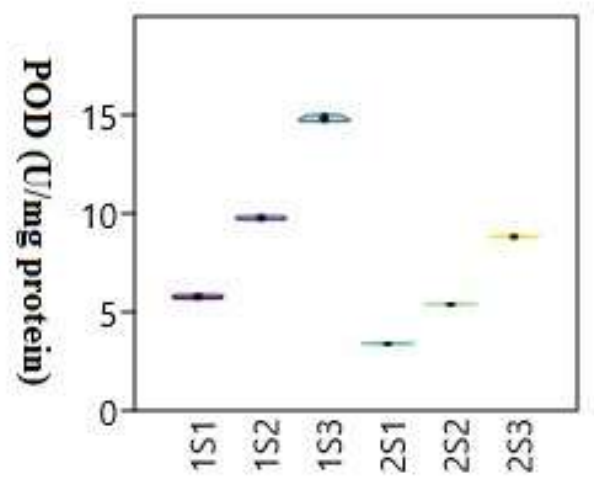

Salinity levels

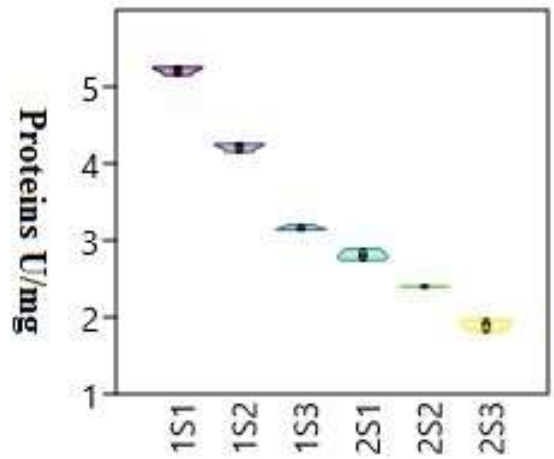

Salinity levels

(a) (b) 


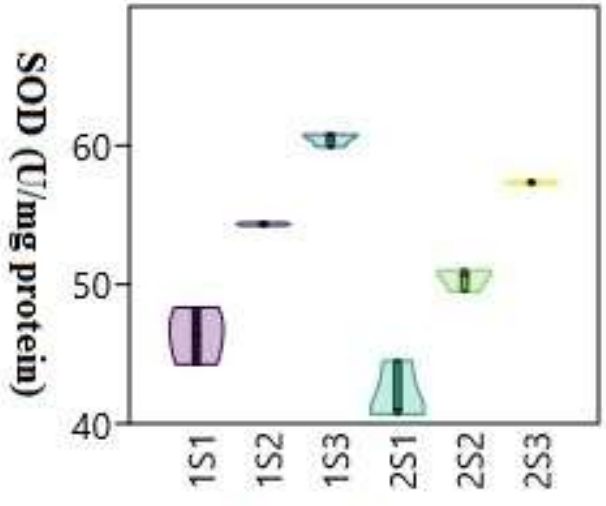

\section{Salinity levels}

(c)

Fig. 4: Biochemical attributes of Conocarpus under different salinity levels 


\section{Discussion}

Inclusive analysis of studied species showed that maximum plant height, biomass and diameter observed in C. lancifolius species. This indicated that $C$. lancifolius species is more salt tolerant that $C$. erectus. Ashraf et al. [13] also reported similar results. The study of Ashraf et al. [13] was carried out on the growth performance of different plant species under different salts stress levels. The range of salinity was $4-25 \mathrm{dSm}^{-1}$. Regarding data of branch number, the maximum branches were noted in C. erectus due to their genetic ability to produce a greater number of branches. Leaves number were also recorded highest in C. erectus as compared to C. lancifolius.

In present study, chlorophyll was decreased in response to salinity. Soil salinity, drought and species significantly affect the chlorophyll content and their interaction was also found significant. Regarding species, chlorophyll content was increased in C. lancifolius compare to $C$. erectus under salinity. Ionic compositions of leaves revealed significant increase in concentration of $\mathrm{Na}^{+}$in the plant tissue content. Maximum $\mathrm{Na}^{+}$concentration was observed in shoots and leaf tissue of $C$. erectus. The leaves of $C$. erectus species showed least concentration of $\mathrm{K}^{+}$due to replacing ability of $\mathrm{Na}^{+}$to $\mathrm{K}^{+}$. Maintaining higher concentration of $\mathrm{K}^{+}$in C. lancifolius improve the ability to grow under high salinity which showed their ability to salt tolerance. Maintaining $\mathrm{K}^{+}$and $\mathrm{Na}^{+}$in plant tissues is important factor to define the ability to salt tolerance [14]. Plant can restrict the accumulation of $\mathrm{Na}^{+}$ in their leaf under salinity stress so that it can get rid of these harmful ions by shedding of their leaves. This is another adaptation by plant to tolerate high salt stress to survive under saline conditions. Water and ion homeostasis may damage plant vascular path, decreased growth, yellowing of leaves leading to plant death [15].

The growing plants in this study also affect the soil chemical properties like $\mathrm{pH}, \mathrm{EC}$ and SAR. Maximum reduction of SAR was observed in this study at site-II (highest salinity level). Basava raja et al. [16] found similar results in his study. Reduction in soil chemical properties was more in case of $C$. lancifolius as compared to C. erectus. Regarding soil physical properties, soil where C. lancifolus grown show better soil physical properties than that of $C$. erectus. Similar findings were reported by Akhter et al. [17], who observed that Kallar grass increased the soil porosity and water holding capacity, while reduced the bulk density under saline sodic soils. Similar results were also found by Mishra and Sharma [18] they conducted an experiment on two leguminous trees i.e Prosopis juliflora and Dalbergia sissoo results of their study also increased soil porosity and reduced bulk density with addition of organic matter to soil at end of experimental period. Organic matter addition can also improve the soil porosity and soil structure. Present inquiries at the end of experimental period increased organic content in C. lancifolius due less shading effect. Conocarpus plantation species under saline sodic soil increased organic matter in soil [13].

\section{Conclusions}

Present inquiries outspread the variations in the physio-morphological and biochemical characteristics of two Conocarpus species against different salt levels. Results revealed that maximum values of stomatal conductance $\left(233 \mathrm{mmol} \mathrm{m}^{-2} \mathrm{sec}^{-1}\right)$, transpiration rate $\left(4.57 \mathrm{MMOL} \mathrm{M}^{-2} \mathrm{~S}^{-1}\right)$, photosynthetic rate $\left(8.76 \mu \mathrm{mol} \mathrm{m}^{-2} \mathrm{sec}^{-1}\right)$ in C. lancifolius. Conocarpus lancifolius and Conocarpus erectus has maximum SOD (13.29 and 19.62) and CAT (16.48 and 42.05), and POD (14.81 and $8.81 \mathrm{U} / \mathrm{mg}$ protein) respectively. Maximum values of $\mathrm{Na}^{+} \mathrm{K}^{+}$ratio in leaves (3.08), shoots (5.98) and roots (9.84) were detected at site-I in C. lancifolius.

Author Contributions: Project was designed and data was collected by AS, AC, and critically analyzed by TH, MU, MA, AH, MAK, ZI, MA, RM.

Funding: This research received no external funding.

Conflicts of Interest: The authors declare no conflict of interest. 


\section{References}

1. Olusegun A.J. and Samuel. A.A.(2014). Assessment of soil sediments and salinity status of wetland landscape as affected by climate change in south-western Nigeria. Stand. Global J. Agric. Sci. 1(1):001-009.

2. Jbir-Koubaa R., Charfeddine S., Ellouz W., Saidi M.N., Drira N., Gargouri-Bouzid R. and O.Nouri-Ellouz. (2014). Investigation of the response to salinity and to oxidative stress of interspecific potato somatic hybrids grown in a greenhouse. Plant Cell Tiss. Organ Cult.120:933-947.

3. Murtaza B., Murtaza G., Rehman M. Z. and Ghafoor A.(2011). Use of brackish water for the reclamation of dense saline-sodic soils by auger hole technology and economic growth of wheat crop. Pak. J. Agri. Sci. 48:269-276

4. AzevedoNeto A.D., Prisco J.T., Eneas-Filho J., Abreu C.E.B. and Filho E.G.(2006). Effect of salt stress on antioxidative enzymes and lipid peroxidation in leaves and roots of salt-tolerant and salt-sensitive maize genotypes. Environ. Exp. Bot. 56: 87-94.

5. Majeed A., Nisar M.F. and Hussain K.(2010). Effect of saline culture on the concentration of $\mathrm{Na}^{+}, \mathrm{K}^{+}$and $\mathrm{Cl}^{-}$in Agrostistolonifera. Curr. Res. J. Biol. Sci. 2(1):76-82.

6. Batool N., Shahzad A., Ilyas N. and Noor T.(2014). Plants and Salt stress. Intl. J. Agri. Crop Sci. 7(9):582-589.

7. Yadav S., Irfan M., Ahmad A. and Hayat S.(2011). Causes of salinity and plant manifestations to salt stress: A review. J. Environ. Biol. 32:667-685.

8. Gilman E.F. and Watson D.G.(1993). Conocarpus erectus, Buttonwood. Fact Sheet ST-179 U.S. Forest Service and Southern Group of State Foresters, Gainesville, USA.

9. Popp M., Uttge U. L., Cram W.J., Diaz M. Griffiths H., Lee H.J.S., Medina E., Schafer C., Stimmel K.H. and Thonke B.(1989). Water relations and gas exchange of mangroves. New Phytologist. 111:293-307.

10. Suleiman M.K., Bhat N.R., Abdal M.S and Bellen R.R(2005). Testing newly introduced ornamental plants to the arid climate of Kuwait. Archives of Agron. and Soil Sci., 51:469-479.

11. Klute A. (1986). Methods of soil analysis.Part 1.Agronomy 9, Soil Science Society of America, Madison, WI.

12. Chance M. and Maehly A.C.(1955). Assay of catalases and peroxidases. Methods Enzymol. 2:764-817.

13. Ashraf M.Y., Shirazi M.U., Ashraf M., Sarwar G. and Khan M.A.(2008). Utilization of salt-affected soils by growing some acacia species. P. 289-311. In: M.A. Khan and D.J. Weber (eds.) Ecophysiology of high salinity tolerant plants.Springer, the Netherlands.

14. Saqib M., Zorb C., Rengel Z. and Schubert S.(2005). $\mathrm{Na}^{+}$exclusion and salt resistance of wheat (Triticumaestivum) are improved by the expression of endogenous vacuolar $\mathrm{Na}^{+} / \mathrm{H}^{+}$antiporters in roots and shoots. Plant Sci. 169:959-965.

15. Zhu J.K. (2001). Plant soil tolerance. Trends Plant Sci. 6:66-71.

16. Basavaraja P.K., Sharma S.D., Dhananjaya B.N and Badrinath M.S.(2011). Acacia nilotica: A tree species for amelioration of sodic soils in Central dry zone of Karnataka, India.19th World congress of soil science, soil.

17. Akhter J., Murray R.,Mahmood K., Malik K.A. and Ahmed S. (2004). Improvement of degraded physical properties of a saline-sodic soil by reclamation with kallar grass (Leptochloafusca). Plant Soil.258:207-216.

18. Mishra A. and Sharma S.D.(2003). Leguminous trees for the restoration of degraded sodic wasteland in the eastern Uttar Pradesh, India. Land Degrad. Dev. 14:245-261. 